scientists who often have to work in comparative isolation at widely separate places. A number of invited papers from abroad on the oceanography of adjacent regions or on more general problems of oceanography formed a background for the symposium.

The amount of resources devoted to marine science in Brazil is still not great, but as a visitor ono could not help being deeply improssed by what has been achieved on slendor resources and particularly by the great enthusiasm displayod by the younger sciontists. In all fiolds the awareness of the need for aiming at quality rathor than quantity of work stood out very clearly. There is a growing appreciation of the importance of oceanography to the country. The need to loarn more about available fisheries and to deal with the problems of defence of a very long coastline has stimulated interest in the Government and in particular in the Navy. Indeed, the Hydrographic Office has with the help of Unesco already almost completed the reconstruction of a research vessel, Almirante Saldanha, which will rank among the largest in the world. She will have an enormous potential for making much needed observations in the Brazil current, but it is to be hoped that such splendid facilities for making observations will not submerge the promising laboratory work which is also gaining impotus. Descriptive ocoanography in all disciplines must be paralleled with adequate theoretical and experimental work before we can expect to reach a real understanding of what happens in the sea. Brazil has the potential to undertake these investigations, and it is hoped that adequate support will be found for them.

Ronald I. CURRIE

\title{
APPLICATIONS OF MICROFILM READERS IN PETROGRAPHY
}

$\mathrm{M}$ ICROFILM recording of original documents is established practice, so also is the use of microfilm readors in their enlargement. In the more spocialized field of potrographic investigations of igneous, metamor. phic and sedimentary rocks, the use of microfilm readors in direct analysis of these materials may not be so generally known. In an article by Radco Kühnel, of the Institute for Minoralogy, Petrography and Geochemistry, Mining Academy, Ostrava, U.S.S.R. (English translation), entitled "Microfilm Reader in Potrography" (Jena Review, No. 3, 1964; VEB Carl Zeiss Jena, Jona (Saalo)), the potentialities of this adaptation of a modern technique are both lucidly explainod and convincingly illustrated.

Taking the ordinary thin section of a rock of conventional thickness about $30 \mu$, as normally examined undor a petrological microscope, and assuming that the averago sizo of the slide fits eomfortably within a $35-\mathrm{mm}$ microfilm frame (which according to European custom it should do), then the simple process of placing the thin section undor the microfilm reader results in a magnified natural image of the section, coloured if appropriate minerals are present, giving not only a clue to identification of at least some of the more easily recognized constituents, but equally to the microstructure and texture of both rock and minerals scrutinized. One initial advantage of this approach to a petrographic investigation is that the whole rock-slice, within the reador frame, can be seen as one field and in complete continuity, avoiding any interrup. tion in analytical assessment of mineral composition and microstructure sometimes occasioned by constantly changing horizontal and vertical orientations of those featuros in the normal course of microscopical examination. There is of course nothing new in projection of part or, if the original image is small enough, the whole of a thin section of rock or particlos by a petrological microscope and suitable optical bonch and illumination, on to an appropriate wall-scroen, especially for class-instructional or other demonstration purposes; but the microfilm reader, properly adapted, simplifies this operation.
Among advantages claimed by the author for microfilm reador technique, he mentions the following: ". . . measuremonts may be carried out on mm-graph paper, otc. ... for dotermining the absolute size of the individual grains ... the grain-bonding figure (average number of adjoining grains)". "As regards the texture, it is a simple mattor to ascertain the regularity of the spatial distribution as well as the orientation of the individual minerais. ... . In certain rocks (especially those rich in molanocratic constituents) it is possiblo to carry out modal determinations by means of a self-produced lattico. . . . Especially in sediment petrography it has given invaluable service in the investigation of the fine stratification, in post-sedimentary deformations, rhythmic precipitations, of gradation symptoms and other lithological phenomena." It is also possible to use this apparatus to explore thin sections of rocks in polarized light and with crossed nicols on the available projection area of the instrument, and with a more powerful lightsource if it is desired to project the image on to a wallscroen for instructional purposes. Another application of the microfilm reader is in photographic documentation of rock micro-structure and micro-texture. In this connexion the author briefly describes his work on 'negative micro-exposures', that is, on direct exposure of the section to photographic paper; he also indicates the possibility of producing direct micro-colour photographs of rocks and minerals by means of coloured reversal paper.

VEB Carl Zeiss Jena (C. Z. Scientific Instruments, Ltd., London, W.1) manufacture what they call a 'Dokumator Film Reader' which appoars to be ideal for the purposes doscribed here. In this apparatus the image appears on a $300 \mathrm{~mm} \times 390 \mathrm{~mm}$ screen of high reflective powor. An attachment for slides permits viewing of glass slides up to $50 \mathrm{~mm} \times 50 \mathrm{~mm}$ in area, but it is to bo noted that some special arrangements would have to be made if conventional British $75 \mathrm{~mm} \times 25 \mathrm{~mm}$ glass slides are involved; altornatively, the smaller foreign-type mounts might have to be used.
H. B. Milner

\section{SUB-UNITS OF THE CATALASE MOLECULE SEEN BY ELECTRON MICROSCOPY}

\author{
By Dr. R. C. VALENTINE \\ National Institute for Medical Research, Mill Hill, London, N.W.7
}

$\mathrm{C}$ ILEAR pictures of protein molecules are difficult to obtain with the electron microscope, although in size the molecules should be easily within its rosolving power. At present, negative staining is the most generally successful way of showing detail down to the molecular level. This is done by drying some dense but unreactive substance with the specimen; the relatively electron. transparent objects are outlined by the far more opaque 'negative stain'. When applied to protoin molecules, this technique works less well with some proteins than with 